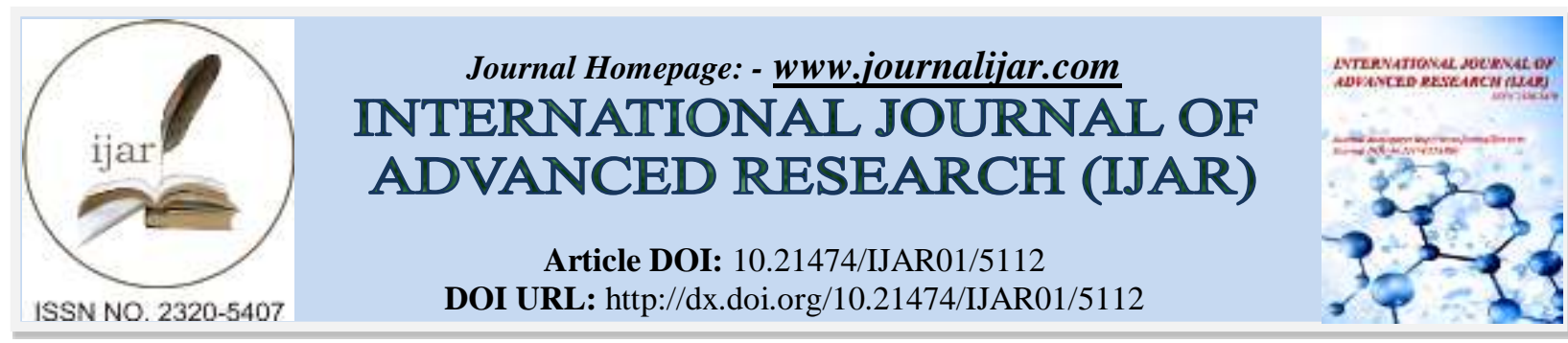

RESEARCH ARTICLE

\title{
EFFECTIVE TEACHING OF MORAL INSTRUCTION: A STRATEGY FOR REPOSITIONING NIGERIA YOUTHS IN THE 21ST CENTURY.
}

\author{
Dr. Nkechi C. Njoku. \\ Department of Arts and Social Science Education, Ebonyi State University, Abakaliki, Ebonyi State, Nigeria.
}

\section{Manuscript Info}

Manuscript History

Received: 09 June 2017

Final Accepted: 11 July 2017

Published: August 2017

Key words:-

Moral instruction, Values, Norms, Objectives of Moral Instruction, Repositioning, Nigerian Youths, Moral behavior.

\begin{abstract}
The study focused on the repositioning of Nigerian youths through the teaching of moral instruction, the study specifically aimed at finding out if the objectives of moral instruction could help in the youths. Two research questions guided the study and a hypothetical statement was raised. The population of the study include all the moral instructors in the 176 secondary schools in Ebonyi state out of which 100 instructors where selected using simple random sampling technique. Questionnaire was the instrument for data collection. Data was analyzed using mean while hypothesis was tested with test at 0.05 level of significance. Results of finding showed that the objectives of moral instruction ore rich enough to inculcate good habit in growing child. Secondly the content of moral education if implemented is capable of repositioning the youth for effective social development. Based on findings recommendations were made.
\end{abstract}

Copy Right, IJAR, 2017,. All rights reserved.

\section{Introduction:-}

The term morality is derived from Latin plural mores meaning manners or morals. The word moral is used to connote code of conducts in a society or within a sub group (Norman, 1973). Morality in a literary term involves a pursuit of good life. Morals could be viewed as actions and inactions that could guide man to relate well with each other in a given society. Moral education or instruction is one of the operational subjects in Nigeria primary and secondary schools. It is an aspect of study that deals with how we ought to live as moral agents in society. Moral instruction could be described as values, norms and knowledge systematically selected and presented to learners to enable them function effectively in society. Moral instruction according to Okoli (1996) refers to chains of organized knowledge which were derived from a given religion to help man achieve his personal measure of insight into the system of the universe. Oxford advanced learners dictionary 6th edition viewed moral instruction as an intellectual way of presenting moral values to learners or an attempt made by teachers to develop moral autonomy in a child through a systematic breeding of the mind.

Judging from these view point, moral instruction therefore is the art of building into the mind of a learner knowledge or fact, values or principles, norms or ethics which can help him/her live peaceful in his society. Repositioning refers to creation of a new stand in something or representing something in a new dimension with the intention of developing a differentiated position in the situation and life of the competitors. Apart from visual identity, it is an overall hauling of a system to enable it meets the standard of present moral challenges. This may involve radical adjustment of functioning of the thing for better service which may affect its identity and behaviour. These changes are geared towards repositioning the person or subject from its negative connotation pre-stand to a positive state.

Address:- Department of Science Education, Ebonyi State University, Abakaliki, Ebonyi State, Nigeria. 
Note that the major reason for repositioning is to communicate a new message or create a new positive usage of the person or thing. In this paper, repositioning refers to corporate restriction of one's behaviour from its selfish position to giving it a personality.

Moral instruction is a process of teaching and giving pieces of advice to another person on moral issues (acceptable behaviours norms, values). It could also refer to doing things which are good and decent and abstaining from bad and indecent behaviours. The morals can vary as much as there are people to teach them; for instance from religions to social moral, from society to personal morals hence moral actions are dependent upon the situation. What we consider immoral in a given society may not be same in other places.

In moral instruction, the role of the instructor is to impact information through directing, counseling and commanding learners to acquire the knowledge. According to Nwachukwu (1995), children learn the norms and values of their society through imitation, observation and instruction. The youths are the growing adults that falls within the age bracket of 16-24, though these age bracket varies because some are youths because of the level of maturity. In this case a child of 13 years could be regarded as a youth. The youths are venerable to crime because of their level of maturity and most often desire to achieve or attain a height quick by fair or foul means due to their inability to internalize the moral codes.

The inclusion of moral instruction in the national curriculum is not accidental, but was informed by the pervasive moral decline especially among the growing youths. Although moral instruction is not examinable yet it is an essential subject designed to inculcate moral values and norms in the lives of learners. The above situation has made the students and teachers not to attach any importance to the teaching of the subject, thereby depriving the subject its rightful place in shaping student's moral life.

The major goal of moral instruction is to assist in the development of compassionate and fair-minded persons who can make positive contributions to society as individuals and members of the group. The essence of this common essential learning is to bring up individuals who would not only be educated, rational, and sympathetic but equally have sense of social responsibility and respect for others. These broad goals have two related objectives: to support students in treating other persons with respect; and to present the students with a better understanding of the personal, moral, social and cultural aspects of school learning (Nwachukwu, 1995).

Nigerian society moreover appreciate the place of moral education in the upbringing of the young adults hence moral instruction was instituted and made compulsory for pupils at every level of primary and secondary school. Judging from the National Policy of Education, moral instruction has two major objectives:

1. Character/moral training required for the development of sound attitudes.

2. Developing in the child the ability to adapt to his environment (NPE, 1981).

These objectives according Nduka and Olonti (1983) could be expanded to incorporate all areas of coverage of moral instruction. Firstly, moral instruction is aimed at building in the pupils the moral habits and good manners. This includes mastering basic good habits and social etiquettes through continuous modeling, inculcation and training. This strand involves learning such specified moral habits like how to greet, talk to elderly, how to make use of public goods, keep close friendship, observe school regulations and its likes.

Secondly, it aims at inculcating moral norms and ideas needed for desirable life. This objective is related to transmitting great moral traditions to the youths. It instils in the pupil a strong commitment to the moral order through persuasive presentation of moral norms, and to develop students' comprehension of the need for a normative structure in the society. This involves learning universal norms or ideas in order to develop the ability to differentiate right from wrong, thereby standing out as a good citizen with the power of doing well to his neighbour.

Thirdly to develop the ability of moral judgment and decision making needed to deal with moral conflict occurring in daily life situation on the basic of discrete moral consideration and justifiable methods. This curriculum strand involves students in practical experiences so that the judgment they make is conscious and deliberate base on their moral autonomy. Development of good sense of judgment helps the students to have a positive thinking over issues that concern him and his environment. 
Fourthly moral instruction aims at building autonomous moral character. This goal deals with inculcating solid moral disposition or a strong moral willingness to do the good by dint of internalization of moral principles and self actualization. This also requires students to develop autonomies voices or lenses on moral issues on the basis of strong moral principles and ideas; and position the students to have a self strength to overcome various harmful temptations. Summarizing the Objectives of moral instruction in repositioning Nigerian youths, Obilo (2005) observed that the major target of moral instruction is to transmit the values of the nation's heritage to the next generation while supporting the autonomous moral development of youths. This aim specifically intend to:

1. Foster the spirit of respect for human dignity and aware of life

2. Nurture those who endeavour to inherit and develop traditional culture and create a culture that is rich.

3. Nurture pupils who in turn will form and develop a democratic society where freedom, truth and peace rules.

4. Train those who can contribute towards realizing a peaceful national society.

5. Train those who can make independent decision and foster a sense of morality.

\section{Statement of Problem:-}

Much has been said about the decline in morality in Nigerian society leading to incessant disobedience, dishonest, social vices, sexual permissiveness and other signs of decadence. The growth of immoral acts and increase in Juvenile crimes made some people to declare that Nigeria is passing through moral crisis. However, most of these immoral acts could be attributed to several causative factors. Some could be attributed to the lack of interest in the teaching of moral and social values in our public schools. Thus, in consideration of the roles school could play in development of the youths, this study sought to find out if moral instruction could be used in repositioning Nigerian youths. Therefore, the problem of this study is how to use the teaching of moral instruction in repositioning Nigerian youths considering the rising trend of immorality in the society.

\section{Research Questions:-}

The following research questions guided the study:

1. What are the objectives of moral instruction in Nigerian schools?

2. In what ways could the teaching of moral instruction in schools help in repositioning the moral behaviour of Nigerian youths?

\section{Hypothesis:-}

There is no significant difference in the mean response scores of male and female moral instructors on the place of moral instruction in the repositioning of Nigerian youths.

\section{Methodology:-}

Descriptive survey design was adopted for the study. The population of the study consists of all the 176 secondary schools in Ebonyi state. 50 secondary schools were sampled out of the 176 schools through simple random sampling technique, while accidental sampling technique was adopted in selection of 100 moral instructors from the 50 selected secondary schools (Two moral instructors were selected from each school). This brings the target population to 100 moral instructors. Questionnaire was the instrument for data collection and face validation was carried out by some experts in educational measurement and evaluation. The instruments were distributed to all the selected instructors in the sampled schools. Mean was used to analyze the data.

A decision rule was derived by adding the assigned values and dividing it by the number scores. Therefore any score below 2.5 is interpreted as rejected and 2.5 and above interpreted as accepted. The assigned scores $=4+3+2+1=$ 10 .The number of scales $=4$, therefore, $10 / 4=2.5$.

\section{Results of the Study:-}

Table 1:- Mean Scores of respondent on objectives of Moral Instruction

\begin{tabular}{|l|l|l|l|l|l|l|l|l|}
\hline S/N & Items & SA & A & D & SD & Total & $\bar{x}$ & Remark \\
\hline & Objectives of Moral Instruction Include: & & & & & & & \\
\hline 1. & $\begin{array}{l}\text { Inculcating moral habits and good manner in } \\
\text { school children. }\end{array}$ & 52 & 48 & - & - & 352 & 3.52 & Accepted \\
\hline 2. & $\begin{array}{l}\text { Helping students to appreciate common values } \\
\text { such as love, honesty and fairness, }\end{array}$ & 58 & 2 & - & 336 & 3.36 & Accepted \\
\hline 3. & Exposing children to acquire moral habits that & 49 & 51 & - & - & 349 & 3.49 & Accepted \\
\hline
\end{tabular}




\begin{tabular}{|l|l|l|l|l|l|l|l|l|}
\hline & $\begin{array}{l}\text { will help them live a good live and become } \\
\text { productive to the nation. }\end{array}$ & & & & & & \\
\hline 4. & $\begin{array}{l}\text { Equipping school children with proper } \\
\text { behaviours towards others in the society. }\end{array}$ & 60 & 40 & - & - & 360 & 3.6 & Accepted \\
\hline 5. & $\begin{array}{l}\text { Training individuals who can form and develop } \\
\text { a democratic society. }\end{array}$ & 90 & 10 & - & - & 390 & 3.9 & Accepted \\
\hline 6. & $\begin{array}{l}\text { Nurturing students who will inherit and } \\
\text { develop traditional culture. }\end{array}$ & 30 & 40 & 16 & 14 & 286 & 2.86 & Accepted \\
\hline 7. & $\begin{array}{l}\text { Fostering in the pupils spirit of respect for } \\
\text { human dignity and awe of life. }\end{array}$ & 40 & 52 & 8 & - & 332 & 3.32 & Accepted \\
\hline 8. & $\begin{array}{l}\text { Building autonomous moral character. } \\
\text { Building in the children good moral judgment } \\
\text { and decision making needed to deal with moral } \\
\text { conflict. }\end{array}$ & 90 & 60 & - & - & 340 & 3.40 & Accepted \\
\hline 9. & $\begin{array}{l}\text { Developing in the learner the ability of } \\
\text { differentiate right from wrong. }\end{array}$ & 100 & - & - & - & 400 & 4.00 & Accepted \\
\hline 11. & $\begin{array}{l}\text { Inculcating in the pupils the desired norms and } \\
\text { ideals needed for smooth relationship with } \\
\text { one's environment. }\end{array}$ & 90 & 10 & - & - & 390 & 3.9 & Accepted \\
\hline & Grand mean & & & & & & $\mathbf{3 . 5 6}$ & Accepted \\
\hline
\end{tabular}

Table 1 above revealed that inculcation of good habit and manner in school children, helping students to appreciate common values, equipping them with proper behaviour towards others, training individuals who can develop a democratic society, fostering in children the spirit of respect for human dignity, building in children good moral judgment and decision making required to deal with the moral conflict are objectives of moral instruction. The grand mean of 3.56 shows high level of acceptance of the above items as objectives of moral instruction.

Table 2:-Mean Scores on how the Teaching of Moral Instruction could help in Repositioning the moral behaviour of Nigerian Youths.

\begin{tabular}{|l|l|l|l|l|l|l|l|l|}
\hline S/N & Items & SA & A & D & SD & Total & $\bar{x}$ & Remark \\
\hline & $\begin{array}{l}\text { The teaching of moral instruction would help } \\
\text { moral behaviour of the youths through: }\end{array}$ & & & & & & & \\
\hline 12. & Inculcating in the youth good conscience. & 70 & 30 & - & - & 370 & 3.70 & Accepted \\
\hline 13. & Building up good sense of judgment & 66 & 32 & 1 & 1 & 363 & 3.63 & Accepted \\
\hline 14. & $\begin{array}{l}\text { Cultivating in the youth the values of obedience, } \\
\text { honest and hardworking. }\end{array}$ & 50 & 47 & 1 & 2 & 363 & 3.63 & Accepted \\
\hline 15. & $\begin{array}{l}\text { Developing in them the spirit of social } \\
\text { conformity. }\end{array}$ & 48 & 59 & 2 & 1 & 374 & 3.74 & Accepted \\
\hline 16. & Making them to be autonomous inaction. & 30 & 50 & 10 & 10 & 300 & 3.00 & Accepted \\
\hline 17. & Reorienting them on the value system & 40 & 40 & 2 & 17 & 302 & 3.02 & Accepted \\
\hline 18. & Transforming the moral life of students & 60 & 40 & - & - & 360 & 3.60 & Accepted \\
\hline 19. & Developing of sympathy for others in need. & 45 & 60 & 5 & - & 310 & 3.10 & Accepted \\
\hline 20. & $\begin{array}{l}\text { Helping the pupils to overcome their emotional } \\
\text { imbalance. }\end{array}$ & 70 & 29 & 1 & - & 369 & 3.69 & Accepted \\
\hline 21. & Providing good sense of discipline & 35 & 65 & - & - & 335 & 3.35 & Accepted \\
\hline 22. & Inculcating in them respect for others & 25 & 75 & - & - & 325 & 3.25 & Accepted \\
\hline 23. & $\begin{array}{l}\text { Predisposing children to the golden rule of } \\
\text { reciprocity. }\end{array}$ & 50 & 39 & 2 & 9 & 330 & 3.33 & Accepted \\
\hline 24. & Building in the pupils the ego ideal & 30 & 48 & 2 & 10 & 280 & 2.80 & Accepted \\
\hline 25. & Helping the pupils to develop self control. & 70 & 30 & - & - & 370 & 3.70 & Accepted \\
\hline & Grand Mean & & & & & & $\mathbf{3 . 3 8}$ & Accepted \\
\hline
\end{tabular}

Table 2 above showed that the respondents agreed that inculcation of good conscience, building sense of judgment, inculcating in the child value of obedience, honest, hardworking etc, developing in them the spirit of social conformity, making them to be autonomous in action, developing sympathy for others in need, providing good sense 
of discipline, respect for others, building in them good ego, self control, and predisposing them to the golden rule of reciprocity are ways by which the teaching of moral instruction could help in repositioning the moral life of the youth.

\section{Hypothesis:-}

Ho1: There is no significant difference in the mean responses of male and female teachers on the place of moral instruction in repositioning of Nigerian youths.

\begin{tabular}{|l|l|l|l|l|l|l|l|}
\hline Gender & $\mathbf{N}$ & $\bar{x}$ & SD & df & t-cal & t-critical & Decision \\
\hline Male & 58 & 3.35 & .37 & & & & \\
\hline & & & & 98 & 1.71 & 1.96 & Accepted \\
\hline Female & 42 & 3.30 & .49 & & & & \\
\hline
\end{tabular}

This shows that the t-critical value of 1.96 is greater than the $t$ - calculated value of 1.71 . Thus, the null hypothesis was accepted. This means that there is no difference in the mean response scores of male and female moral instructors on the place of moral instruction in repositioning of Nigerian youths.

\section{Discussion:-}

Results of the study in Table 1 showed that respondents agreed with inculcation of good habits and good moral judgments are objectives of moral instruction. This was evident from the grand mean of 3.56 which is above the criterion mean of 2.50. The finding was understandable based on moral training is the fundamental goal of every education hence the objectives are geared towards building in the life the young common essential norms or learning capable of giving man a sense of social responsibility.

This is in line with Oser and Reichenbach (1994) that the objectives of moral instruction are detailed and rich enough to deal with the present moral crisis in the society. This means that the aims and objectives of moral instruction are arranged to equip one with the required moral values for an active and responsible integration against social evil.

The findings on the teaching of moral shaping behavior with a grand mean of 3.38 showed that the teaching of moral instruction could help in shaping one's moral behavior which in turn repositions him for a sustainable development. The finding here is interesting in that the study disclosed how the teaching of moral instruction could inculcate in the learner good manners which in turn help adapt in his environment.

In line with the findings on the place of instruction in repositioning the youths, Flugel (1995), was of the view that the essence of moral instruction in schools is to reinforce in the youths the social virtues acquired at home so that children can apply them in schools and then in the society at large for effective relationship. The teaching of moral instruction emphasizes the need for human respect and good relationship especially in Nigeria where people are always identified in a group. This relationship is stressed throughout the entire school life to extent of predisposing the young adult to live in harmony with the neighbours. According to Malikail and Stewart (1987) the implication of moral instruction in schools lies in the relationship between the individual and the national development. When individual is developed, the nation is implicitly developed. Moral poverty of an individual is the greatest that any nation can suffer. Therefore the primary objective of moral instruction is building up the individual that would develop his society. Okoli (1996) highlighted the roles of moral instruction to include: self awareness relationship with others; understanding of different beliefs, values and practices. This includes acquiring sense of moral judgment about what is wrong or right.

Gender differences in teaching of moral instruction were examined in relation to repositioning of Nigeria youths. The result revealed that there is no significance difference in the mean response scores of male and female teachers on the place of moral instruction in repositioning of Nigerian youths. Therefore, the null hypothesis was accepted.

\section{Conclusion:-}

The findings of the study revealed that the objectives of the study are detailed enough to deal with the moral decadence in the society since the major objective of establishing moral instruction is to inculcate values, norms and knowledge into the life of the learner so that he/she would contribute positively as a member of the group. In addition to this, the teaching of moral instruction contains the common essential ingredients that could reposition the 
youth for further development. It is my conclusion that effective teaching of moral instruction will lead to proper repositioning of Nigerian youths for positive thinking and action.

\section{Recommendations:-}

The following recommendations were made based on the finding:

1. Moral instructors should endeavour to achieve the set objectives of moral instruction.

2. Moral instructors should teach learners those norms and values that could enhance good moral behaviour.

3. Moral instructors should ensure that every student at primary and secondary level of education attend moral instruction lessons as a sure step towards repositioning the youths.

4. Moral instruction should be made an examinable subject as well as proper evaluation should be carried out as done in other subjects.

5. The government and educational planners should sensitize the students through media on the need for moral training.

6. The curriculum designer should state boldly the objectives of moral instruction.

7. Moral instructors should employ versatile strategies while teaching moral instruction, so that it can yield its positive aim of repositioning the youths.

\section{References:-}

1. Beauchamp, E.R. (1985). Education and development of positive education policy. New-York: Anderson Pub. Blair, J. (2005). The value of good home upbringing in the children. Accra: Rel Publishing Co. Ltd.

2. Charles, (200). Education \& Morality in Nigeria. Ibadan: Spectrum books Ltd.

3. Chen, C. M. \& Bowel, R.C. (1995). Attitude towards the public schools. USA: Delta kappa.

4. Encyclopedia Britannica Student and home. (2010). Ethics and morality. Chicago: Pam Publisher.

5. Essuaman, A.C. (2005). Youth in our contemporary society. Enugu: Ph. Publishing Ltd.

6. Ezeanya, S. (1988). Christian Education for our children. Catechism of the catholic church. Onitsha: Tabansi Press Ltd.

7. Federal Republic of Nigeria (1981). National Policy on Education. Lagos: Federal Government Printer.

8. Flugel, J.C. (1995). Man, Morals and society. New-York: Penguin Books.

9. Hannon, P. (2005). Moral decision making. Dublin: veritas Publications. http://www.encylopedia.com/doc/ 1G2-344720034 html 8th October 2009.

10. Ifeadi, F.T. (2006). Moral decadence for colleges and universities. Enugu: fourth Dimension.

11. Iheoma, E. 0. (1995). Moral Education for Colleges and Universities. Enugu: Fourth Dimension publishing.

12. Kelvin, C. (1952). Teaching the religious lesson. Enugu: Macmillan Publishers.

13. Klaus, L. (1990). Moral education in Japan. Journal of moral education. 19.(3) P.172

14. MailKail, A. \& Stewart, C. (1987). Personal and social values and skills. CEL Journal. USA: Springer business media.

15. Nduka, C. \& Olonti, A. (1983). New perspectives in moral education, Enugu: Saps Publishers.

16. Norman, i.B (1996). Moral education, London: Routledge and Kegan Paul Ltd.

17. Nwachukwu, T.A. (1995). Psychology of Learning. Enugu: De Sandax Ltd.

18. Nwakpa, P.N. (2004). Moral decadence in our schools. The bane of our society. The sage 1(4).

19. Obilo, E.E. (1995). Religious education in Nigeria schools and college. Owerri: versatile publishers

20. Okafor, M. (2007). Teaching morality and religious education. London: George Allen and Unwin.

21. Okoli S.C. (1996). Teacher's attitude to moral education of their pupils. Enugu: Saps Publishes.

22. Rebollo, M. (2000). Moral education in the school. Maricla: UST Publishing House.

23. Salihu, N.M. (2007 30 Jan.). Youth urged to shun social vices. Daily Triumph, l(1), 1. 